\title{
Physicochemical water quality parameters in typical rice-crayfish integrated systems (RCIS) in China
}

\author{
Jixin $\mathrm{Yu}^{1,2}$, Yan Ren ${ }^{1,2}$, Tao $\mathrm{Xu}^{3}$, Wei $\mathrm{Li}^{1}$, Mantang Xiong ${ }^{1,2}$, Tanglin Zhang ${ }^{1 *}$, \\ Zhongjie Li ${ }^{1}$, Jiashou Liu ${ }^{1}$ \\ (1. State Key Laboratory of Freshwater Ecology and Biotechnology, Institute of Hydrobiology, Chinese Academy of Sciences, \\ Wuhan 430072, China; \\ 2. University of Chinese Academy of Sciences, Beijing 100049, China; \\ 3. College of Biological and Pharmaceutical Sciences, China Three Gorges University, Yichang 443002, China)
}

\begin{abstract}
To determine the variation of water quality in rice-crayfish (Procambarus clarkii) integrated systems (RCIS) in China, eleven water quality parameters were measured monthly in a typical RCIS located in Qianjiang City (Hubei Province) from July 2014 to June 2015, the parameters were analyzed with principal component analysis (PCA) and compared between the trenches and rice areas during the rice fallow period (Nov-May). The trench and rice area comprehensive results showed that $\mathrm{pH}(7.48-8.68), \mathrm{NH}_{4}{ }^{+}-\mathrm{N}(0.2-1.09 \mathrm{mg} / \mathrm{L}), \mathrm{NO}_{2}{ }^{-} \mathrm{N}(<0.052 \mathrm{mg} / \mathrm{L})$ and conductivity $(435-951 \mu \mathrm{S} / \mathrm{cm})$ were within the suitable ranges for $P$. clarkii and that turbidity (TU) was high during the crayfish harvesting and rice planting season. Annual averages of total nitrogen (TN), total phosphorus (TP), permanganate index $\left(\mathrm{COD}_{\mathrm{Mn}}\right)$, and chlorophyll $a($ Chl.a) content were $<2$ (except in Nov-Dec), $0.25,10 \mathrm{mg} / \mathrm{L}$, and $50 \mathrm{mg} / \mathrm{m}^{3}$ (especially in Nov-May, $<10 \mathrm{mg} / \mathrm{m}^{3}$ ), respectively. Dissolved oxygen (DO) was below $4 \mathrm{mg} / \mathrm{L}$ in Mar-Sep, with a minimum of $\sim 1 \mathrm{mg} / \mathrm{L}$, and much higher in Oct-Feb. The maximum and minimum monthly average water temperature (WT) were $31.4^{\circ} \mathrm{C}$ in July and $5.7^{\circ} \mathrm{C}$ in December, while the maximum and minimum instantaneous WT were $39.7^{\circ} \mathrm{C}$ and $2.5^{\circ} \mathrm{C}$, respectively. PCA analysis showed that the first three axes, which were mainly correlated with DO, WT and nutrient level, described most information of the parameters, and parameters showed seasonal changes. Some differences were observed in water parameters between the trenches and rice areas, i.e., trenches generally had higher TU, WT and DO, and lower TN, TP and $\mathrm{COD}_{\mathrm{Mn}}$, although no significant differences were found in some months and some parameters. The study revealed relatively low water nutrient level, probable extreme WT and DO level in some seasons, and certain differences between the trenches and rice areas in typical CRIS in China. Accordingly, some measures should be taken to improve the negative parameters: 1) enhance the water fertility; 2) increase DO, especially in Mar-Sep; 3 ) increase the trench and water depth to avoid extreme WT. And water quality management should be addressed in both trenches and rice areas.
\end{abstract}

Keywords: rice-crayfish integrated system, co-culture, water quality parameters, trench, rice production area, PCA DOI: $10.25165 /$ j.ijabe.20181103.3761

Citation: Yu J X, Ren Y, Xu T, Li W, Xiong M T, Zhang T L, et al. Physicochemical water quality parameters in typical rice-crayfish integrated systems (RCIS) in China. Int J Agric \& Biol Eng, 2018; 11(3): 54-60.

\section{Introduction}

The integration of rice and fish culturing has been successfully practiced for 2000 years and, in addition to food, provides social, economic and ecological benefits ${ }^{[1,2]}$. China has the longest history, the largest area and the highest fish yields of rice-fish coculture in the world ${ }^{[3]}$, with an area of about 1.5 million $\mathrm{hm}^{2}$

\section{Received date: 2017-09-09 Accepted date: 2018-03-04}

Biographies: Jixin Yu, $\mathrm{PhD}$ candidate, research interests: aquaculture, fisheries and freshwater ecology, Email: jxyu001@126.com; Yan Ren, PhD candidate, research interests: aquaculture, Email: renyan@ihb.ac.cn; Tao Xu, $\mathrm{PhD}$, Associate Professor, research interests: pollution ecology, Email: 125345661@qq.com; Wei Li, PhD, Associate Professor, research interests: aquaculture, Email: liwei@ihb.ac.cn; Mantang Xiong, PhD candidate, research interests: freshwater fishery, Email: xiongmantang@ihb.ac.cn; Zhongjie Li: Professor, research interests: aquaculture and fishery ecology, Email: zhongjie@ihb.ac.cn; Jiashou Liu, PhD, Professor, research interests: aquaculture and fishery ecology, Email: jsliu@ihb.ac.cn.

*Corresponding author: Tanglin Zhang, PhD, Professor, research interests: aquaculture and fishery ecology. State Key Laboratory of Freshwater Ecology and Biotechnology, Institute of Hydrobiology, Chinese Academy of Sciences, Wuhan 430072, China. Tel/Fax: +86-27-68780369, Email: tlzhang@ihb.ac.cn.
(24.49\% of the total inland aquaculture areas), and a total yield of 1.56 million tons of fish in $2015^{[4]}$. Although integration of rice with crayfish (Procambarus clarkii) (RCIS) has a short history in China, and it has become popular and profitable, especially in the middle-lower reaches of Yangtze River ${ }^{[2]}$. Until 2009, RCIS accounted for about $60 \%$ of the total annual yield of $P$. clarkii in China, with a total area of $280000 \mathrm{hm}^{2[5]}$, and the yield and culture area are increasing. A Chinese RCIS is typically operated as follows ${ }^{[2,6,7]}$ : Peripheral trenches (2-4 m wide, $\sim 1.5 \mathrm{~m}$ deep) and, if necessary, cross trenches (1-2 $\mathrm{m}$ wide, 0.8-1.2 $\mathrm{m}$ deep) are excavated, and a surrounding fence is set up using materials such as asbestos sheets or polypropylene mesh. Aquatic plants are set to cover $20 \%-50 \%$ of the trench area to provide shelter for crayfish. $300-750 \mathrm{~kg} / \mathrm{hm}^{2}$ of berried crayfish are stocked Oct-Nov, or 150 000-225 000 individual $/ \mathrm{hm}^{2}$ of juvenile crayfish are stocked Mar-May. Crayfish can be stocked annually, or only in the first year if a sufficient number of crayfish are left to reproduce. Supplementary feeding is necessary for high yield production. Trap harvesting of crayfish is carried out Apr-Jun. Middle-season rice is planted in June and harvested in October. The range of yields for crayfish and rice are $750-2250 \mathrm{~kg} / \mathrm{hm}^{2}$ and 
$7500-10500 \mathrm{~kg} / \mathrm{hm}^{2}$, respectively, depending on management, disease and climate.

Research on domestic RCIS has focused on farming techniques ${ }^{[6,7]}$, and few reports have focused on water quality. Water, in deed, is the most important single factor for all aquacultural activities. The growth and survival of crayfish inevitably depend on water quality ${ }^{[8]}$, and crayfish culture strongly effects water quality ${ }^{[9,10]}$. The inundated rice fields used for crayfish culture comprise a special type of wetlands: 1) Rice fields are shallow closed water systems. They are strongly affected by weather conditions, and display large spatial and temporal variations in turbidity, temperature, $\mathrm{pH}$, dissolved oxygen (DO) and nutrient levels ${ }^{[11]}$. 2) Rice fields used for RCIS are mainly maintained and influenced by agricultural activities ${ }^{[11]}$. Water quality changes with cultivation, such as plowing, rice transplanting, fertilization, feeding and crayfish harvesting. 3) Crayfish bioperturbation on the rice field system transforms nutrients from sediments (containing detritus, crayfish feces and residual feed) to water ${ }^{[12]}$. 4) Nutrients of decomposing rice stubble are continuously released to water in rice fallow period. 5) The limited water volume in rice fields limits buffering and self-purification capacity ${ }^{[13]}$. 6) The trenches and rice areas in RCIS share different engineering structure and maintenance, probably presenting different water conditions. In short, changes and trends in water quality are partly caused by the special structure and management of RCIS, and they can indicate strengths and weaknesses of the current operation. For instance, Zhang et al. ${ }^{[13]}$ observed significant differences of water $\mathrm{DO}, \mathrm{NH}_{3}{ }^{+}-\mathrm{N}$, $\mathrm{NO}_{3}{ }^{-}-\mathrm{N}, \mathrm{NO}_{2}{ }^{-} \mathrm{N}$ and $\mathrm{PO}_{4}{ }^{3-}-\mathrm{P}$ between trenches and rice areas in some stages in rice-crab (Eriocheir sinensis) coculture system. Another example, with a water depth similar to trenches in RCIS, $\mathrm{Ni}$ et al. ${ }^{[14]}$ reported frequent water temperature (WT) exceeding $32.2^{\circ} \mathrm{C}$, which is detrimental or even lethal to $P$. clarkii $^{[15]}$ in crayfish ponds during summer. Although Mao et al. ${ }^{[16]}$ reported on the stability of water quality parameters in a Chinese RCIS, but only nutrients (ammonia, nitrate, nitrite and available phosphorus) were measured, and temporal variations were not reported. Thus, variations of water quality parameters of RCIS in China is still to be understood.

The purposes of this study were to: 1) understand the variations of water quality parameters in typical RCIS in China; 2) determine the differences of water quality between the trench and rice area. Eleven physicochemical parameters of water quality, in both trenches and rice areas of a typical RCIS in Qianjiang City, Hubei Province, China, were measured monthly from July, 2014 to June, 2015. Water parameters were then analyzed with PCA, and trench and rice area water were compared during the rice fallow period. Qianjiang City was selected because it is the birthplace of RCIS and "The Land of Crayfish" in China ${ }^{[5,7]}$. The results can reveal the changing patterns of water quality parameters of RCIS, and help RCIS farmers to improve aquaculture practices, such as how to prevent extreme water quality factors, how to improve the field engineering and so on.

\section{Materials and methods}

\subsection{Study site}

The study was conducted at Zhangjiayao Farm, Houhu Management District, Qianjiang City, Hubei Province, China (Figure 1a). Qianjiang City $\left(112^{\circ} 29^{\prime}-113^{\circ} 01^{\prime} \mathrm{E}, \quad 30^{\circ} 04^{\prime}-\right.$ $30^{\circ} 39^{\prime} \mathrm{N}$ ) is located in the hinterland of Jianghan Plain, where rich water resources and wetlands provide excellent crayfish habitats.

\subsection{Agronomic and aquacultural management}

There were 16 rice plots in the study aquafarm (Figure $1 \mathrm{~b}$ and 1c). Each plot was 2.33 ha: 0.33 ha for trenches (four peripheral trenches and a cross one) and 2 ha for rice area. Peripheral trenches of each plot were $1.5 \mathrm{~m}$ deep by $4.0 \mathrm{~m}$ wide and the cross trench was $1.0 \mathrm{~m}$ deep by $1.8 \mathrm{~m}$ wide. Plot inlets and outlets were screened. Elodea nuttallii and Alternanthera philoxeroides were planted in the trenches on March 5, 2014, and maintained at about $20 \%$ coverage and E. nuttallii was also planted in the rice areas during the rice fallow period. Juvenile crayfish (weight of 3-5 g, 15000 individual $/ \mathrm{hm}^{2}$ ) were released on March 20. Crayfish were fed daily with commercial pellets $(28 \%$ crude protein, $4 \%$ crude lipid, $8 \%$ crude fiber, Hubei Kewang Graziery Limited Liability Company) at a rate of $3 \%-8 \%$ of elevated total crayfish weight. The daily amount varied, but totaled $\sim 750 \mathrm{~kg} / \mathrm{hm}^{2}$. Crayfish harvest lasted from April 25 to June 10, and sufficient crayfish were left as breeding stock. The annual crayfish yield was $1560 \mathrm{~kg} / \mathrm{hm}^{2}$.

Middle-season rice (Huanghuazhan) was transplanted on June 20th. Before rice seedling transplantation, the soil and remaining rice straw were ploughed and compound fertilizer was broadcast $\left(\mathrm{N}-\mathrm{P}_{2} \mathrm{O}_{5}-\mathrm{K}_{2} \mathrm{O}: \quad 17-17-17,600 \mathrm{~kg} / \mathrm{hm}^{2}\right)$. Ten days after transplanting, tillering fertilizer and urea $\left(150 \mathrm{~kg} / \mathrm{hm}^{2}\right)$ were broadcast. Rice was harvested in October 16, with rice straw (height of $\sim 35 \mathrm{~cm}$, with roots) left. The annual rice yield was $8900 \mathrm{~kg} / \mathrm{hm}^{2}$. Water addition was performed on October 25 to half-submerge rice straw, and the water level was maintained during the rice fallow period Nov-May.

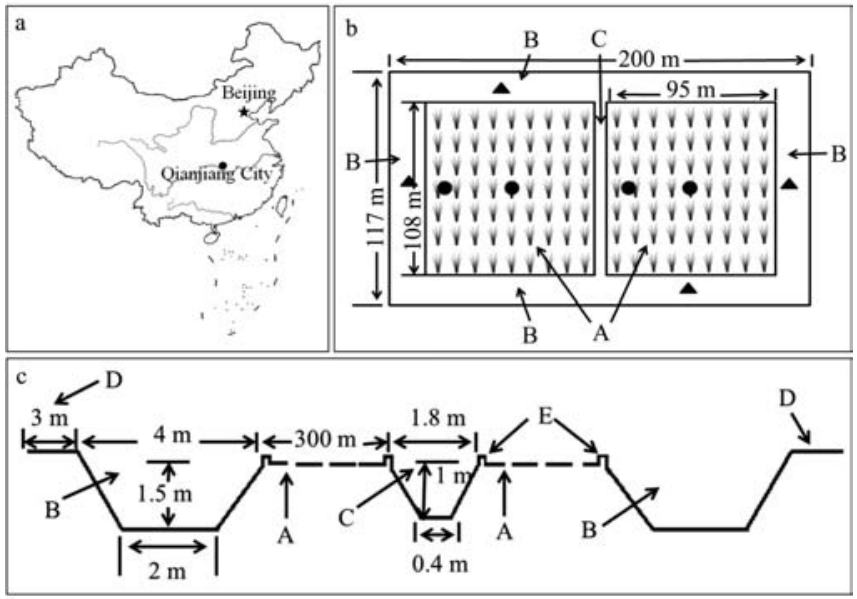

(a) location of study site; (b) plane figure of rice-crayfish plot (dimensions, trench sampling points $\boldsymbol{\Delta}$ and rice area sampling points $\mathbf{O}$ ); (c) cross-section of RCIS plot (A, rice area; B, peripheral trench; C, cross trench; D, plot dike; E, trench dike)

Figure 1 Study site and design of RCIS plots

\subsection{Water quality parameters monitoring}

Four rice plots were selected as replicates and water samples were collected at 8:00-10:00 on the $22^{\text {nd }}$ of each month from July 2014 to June 2015. Four $500 \mathrm{~mL}$ samples were collected in both the peripheral trenches (triangles in Figure 1b) and rice areas (circles in Figure 1b) of each plot. The four samples from each area were combined to give two $2000 \mathrm{~mL}$ composite samples for each plot. TU, WT, DO, conductivity (Cond) and $\mathrm{pH}$ were tested in situ using a HACH $2100 \mathrm{Q}$ turbidimeter and a YSI Pro Plus Multi-Parameter water quality meter. $\mathrm{TN}, \mathrm{NH}_{4}^{+}-\mathrm{N}, \mathrm{NO}_{2}{ }^{-} \mathrm{N}, \mathrm{TP}$, $\mathrm{COD}_{\mathrm{Mn}}$ and Chl. $a$ were measured according to APHA methods ${ }^{[17]}$ in the laboratory. Water during the rice growing season (Jun-Oct) could not be sampled because there was little or no water in the rice areas. 
WT changes quickly with air temperature and monthly monitoring is not sufficient to characterize the annual variations. To obtain highly resolved temporal data, a HOBO Pendant Temperature/Light data logger (Onset Computer Corporation) was placed half a meter below the water surface to record values every two hours during the entire study period.

\subsection{Statistical analyses}

All calculations and statistical analyses were performed using Excel 2003 and R 3.2.4, respectively. The T tests $(p<0.05)$ was used to compare differences between the trench and rice area water parameters. The PCA was performed on a correlation matrix of standardized and transformed data to reduce the dimensionality, with "ade4", "psych" and "factoextra" packages.

\section{Results}

\subsection{Trench water parameters}

Water $\mathrm{pH}$ and Cond varied at 7.48-8.68 (Figure 2a), and 435-951 $\mu \mathrm{S} / \mathrm{cm}$ (Figure 2d), respectively. Maximum and minimum values of average WT were respectively $31.4^{\circ} \mathrm{C}$ in July and $6.5^{\circ} \mathrm{C}$ in December (Figure 2b), and the maximum and minimum instantaneous WT were $39.7^{\circ} \mathrm{C}$ in July and $2.5^{\circ} \mathrm{C}$ in January (Figure 3). DO remained above $4 \mathrm{mg} / \mathrm{L}$ in Oct-Mar and $\leq 3 \mathrm{mg} / \mathrm{L}$ in Apr-Jun, and the lowest value of $1.36 \mathrm{mg} / \mathrm{L}$ was recorded in June (Figure 2c). TU remained relatively low $(<10 \mathrm{NTU})$ in Oct-Mar, and rose sharply in the fishing and planting season (Figure 2e).

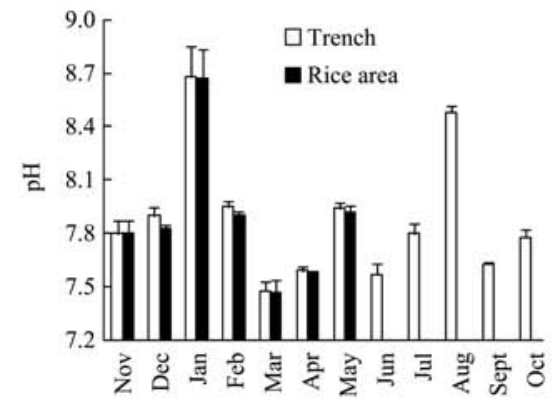

a. $\mathrm{pH}$

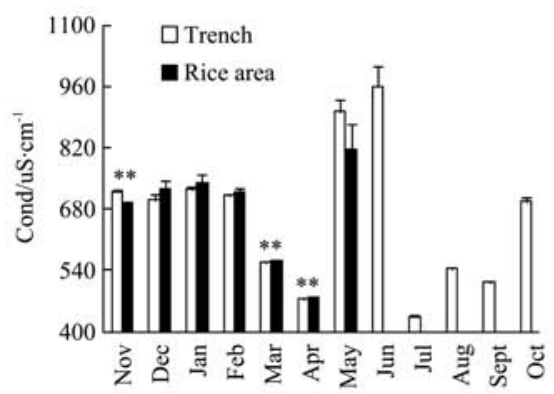

d. Cond

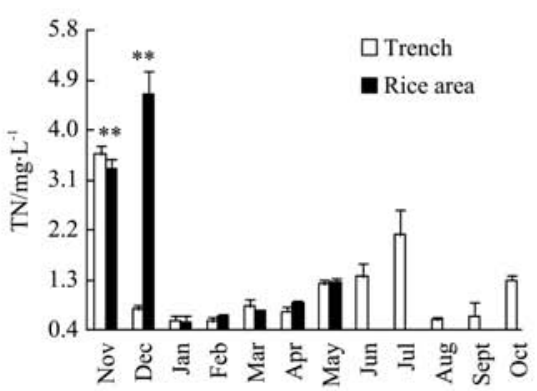

g. TN

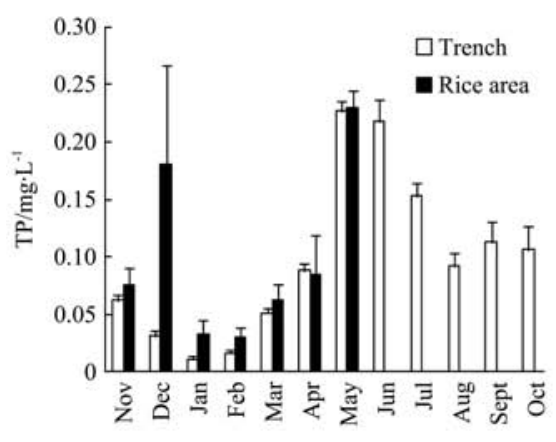

j. TP

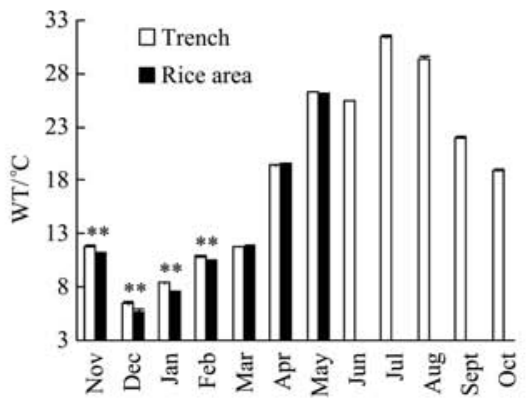

b. WT

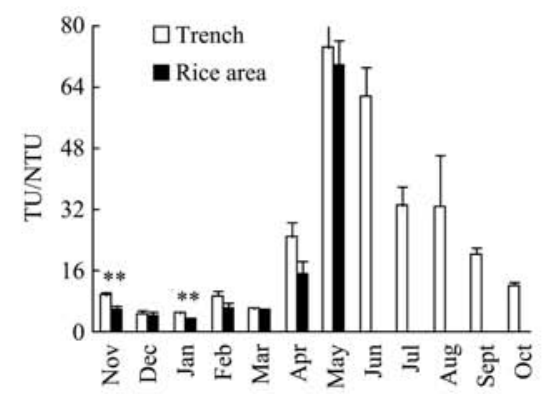

e. TU

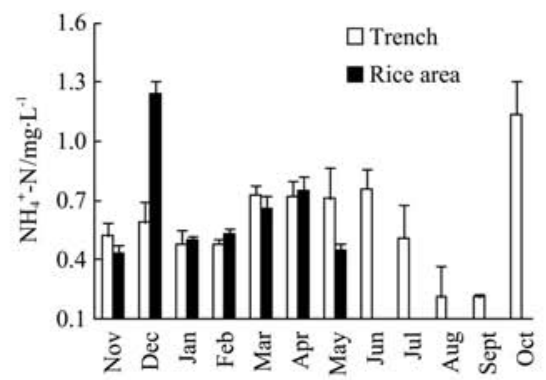

h. $\mathrm{NH}_{4}{ }^{+}-\mathrm{N}$

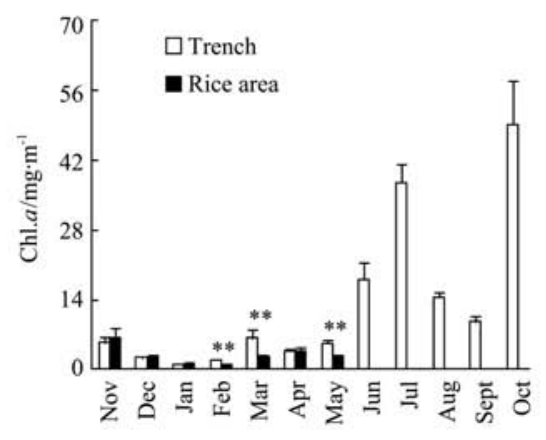

k. Chl.a.

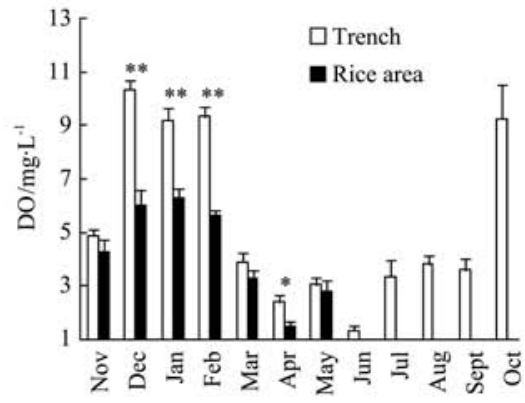

c. DO

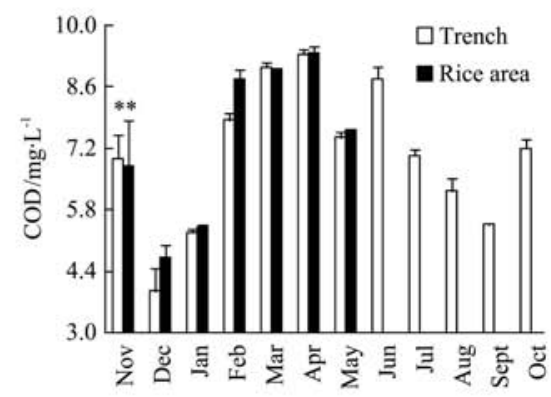

f. $\mathrm{COD}_{\mathrm{Mn}}$

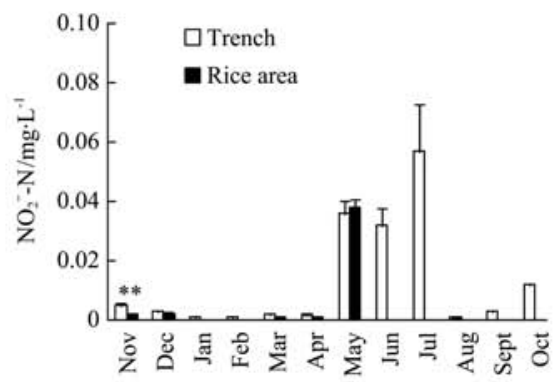

i. $\mathrm{NO}_{2}{ }^{-}-\mathrm{N}$

Figure 2 Water quality parameters in trenches and rice areas of RCIS (mean $\pm \mathrm{SE}$ ). Asterisks represent significant differences between trench and rice area water $(* p<0.05, * * p<0.01)$ 
$\mathrm{COD}_{\mathrm{Mn}}$ varied at $3.74-9.36 \mathrm{mg} / \mathrm{L}$, with a minimum and maximum in December and April, respectively (Figure 2f). TN generally increased Jan-Jul, decreased sharply to the minimum of $0.59 \mathrm{mg} / \mathrm{L}$ in August, increased rapidly through November to $3.57 \mathrm{mg} / \mathrm{L}$ and decreased until January (Figure $2 \mathrm{~g}$ ). $\quad \mathrm{NH}_{4}^{+}-\mathrm{N}$ showed two relatively stable periods Nov-Feb and Mar-Jul, decreased Aug-Sep to the minimum of $0.21 \mathrm{mg} / \mathrm{L}$, and then rose sharply to $1.14 \mathrm{mg} / \mathrm{L}$ in October (Figure $2 \mathrm{~h}$ ). $\quad \mathrm{NO}_{2}{ }^{-} \mathrm{N}$ was nearly always $<0.01 \mathrm{mg} / \mathrm{L}$ except May-Jul, when it peaked at 0.035 $0.052 \mathrm{mg} / \mathrm{L}$ (Figure 2i). TP increased from January, peaked in May-Jun at $0.22 \mathrm{mg} / \mathrm{L}$ and then declined until the next January, excepting a slight rise in September (Figure 2j). Chl. $a$ was below $10 \mathrm{mg} / \mathrm{m}^{3}$ in Nov-May, and relatively high in Jul-Oct (Figure $2 \mathrm{k}$ ).

The results of PCA analysis described $41.97 \%, 18.02 \%$ and $13.26 \%$ of the variance in the water parameters in the first three axes, with the eigenvalues of $3.77,1.62$ and 1.19 , respectively. DO (0.702) showed the highest positive correlation with the first PCA axis, whereas TP $(-0.822), \mathrm{NO}_{2}^{-}-\mathrm{N}(-0.802)$, WT $(-0.789)$, TN (-0.74), Chl.a $(-0.543)$ and $\operatorname{COD}_{\mathrm{Mn}}(-0.529)$ exhibited a negative correlation with this axis. The first PCA axis was related to the eutrophic conditions, temperature and DO in trench water. $\mathrm{COD}_{\mathrm{Mn}}(0.628)$ was positive correlated with the second PCA axis, while DO $(-0.56)$ and Chl. $a(-0.546)$ were negative correlated with this axis (Figure $4 \mathrm{~A})$.

The location of winter (Wi) was separated from the others in the ordination diagraph (Figure 4A). Water in winter showed the highest $\mathrm{DO}$, while summer $(\mathrm{Su})$ exhibited highest eutrophic level and WT, and spring (Sp) and autumn (Au) located in the middle.

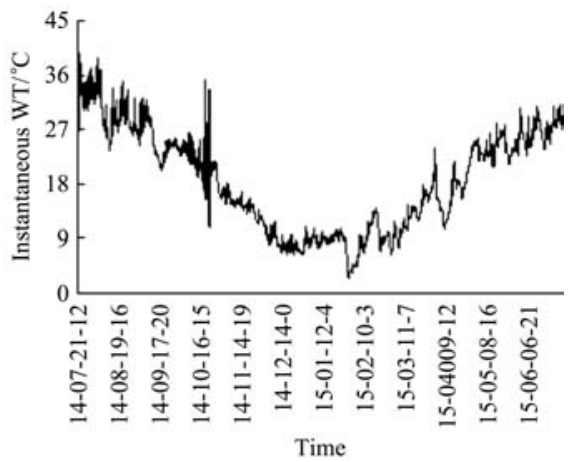

Figure 3 Instantaneous temperature of trench water from July, 2014 to June, 2015

\subsection{Rice area water parameters during the rice fallow period}

During the rice fallow period, the dynamic interaction of rice area water with trench water was reflected in all parameter values, excepting a few occasions with $\mathrm{TN}, \mathrm{NH}_{4}{ }^{+} \mathrm{N}$ and $\mathrm{TP}$ (Figure 2). The range for each parameter was as follows: $\mathrm{pH}, 7.47-8.67$; WT, $(5.7-26.1)^{\circ} \mathrm{C}$; DO, $1.48-6.28 \mathrm{mg} / \mathrm{L}$; Cond, $480-819 \mu \mathrm{S} / \mathrm{cm}$; TU, 4.28-69.83 NTU; $\mathrm{COD}_{\mathrm{Mn}}, 4.72-9.36 \mathrm{mg} / \mathrm{L} ; \mathrm{NO}_{2}^{-}-\mathrm{N}, 0-0.038 \mathrm{mg} / \mathrm{L}$ and Chl.a, $0.90-6.50 \mathrm{mg} / \mathrm{m}^{3}$. TN peaked in Nov-Dec, declined drastically in January, and then showed a slow increase (Figure 2g). $\mathrm{NH}_{4}{ }^{+} \mathrm{N}$ and $\mathrm{TP}$ displayed seasonal variations similar to TN, excepting in May (Figure $2 \mathrm{~h}$ and $2 \mathrm{j}$ ).

The first three axes described $40.02 \%, 22.84 \%$ and $20.72 \%$ of the variance in the water parameters in the PCA analysis, with the eigenvalues of 3.60, 2.06 and 1.86, respectively. $\mathrm{DO}(0.945), \mathrm{pH}$ (0.67) and Cond (0.564) showed the highest positive correlation with the first PCA axis, whereas WT $(-0.749), \operatorname{COD}_{\mathrm{Mn}}(-0.693)$ and TP $(-0.666)$ exhibited a negative correlation with this axis. Chl. $a(-0.743)$ and TN $(-0.67)$ were negative correlated with the second axis (Figure 4B).
The location of winter (Wi) in the ordination diagraph indicated its strong correlation with Cond, $\mathrm{pH}$ and $\mathrm{DO}$, while spring (Sp) with WT, $\mathrm{COD}_{\mathrm{Mn}}$ and TP, and autumn (Au) with Chl.a and TN (Figure 4B).

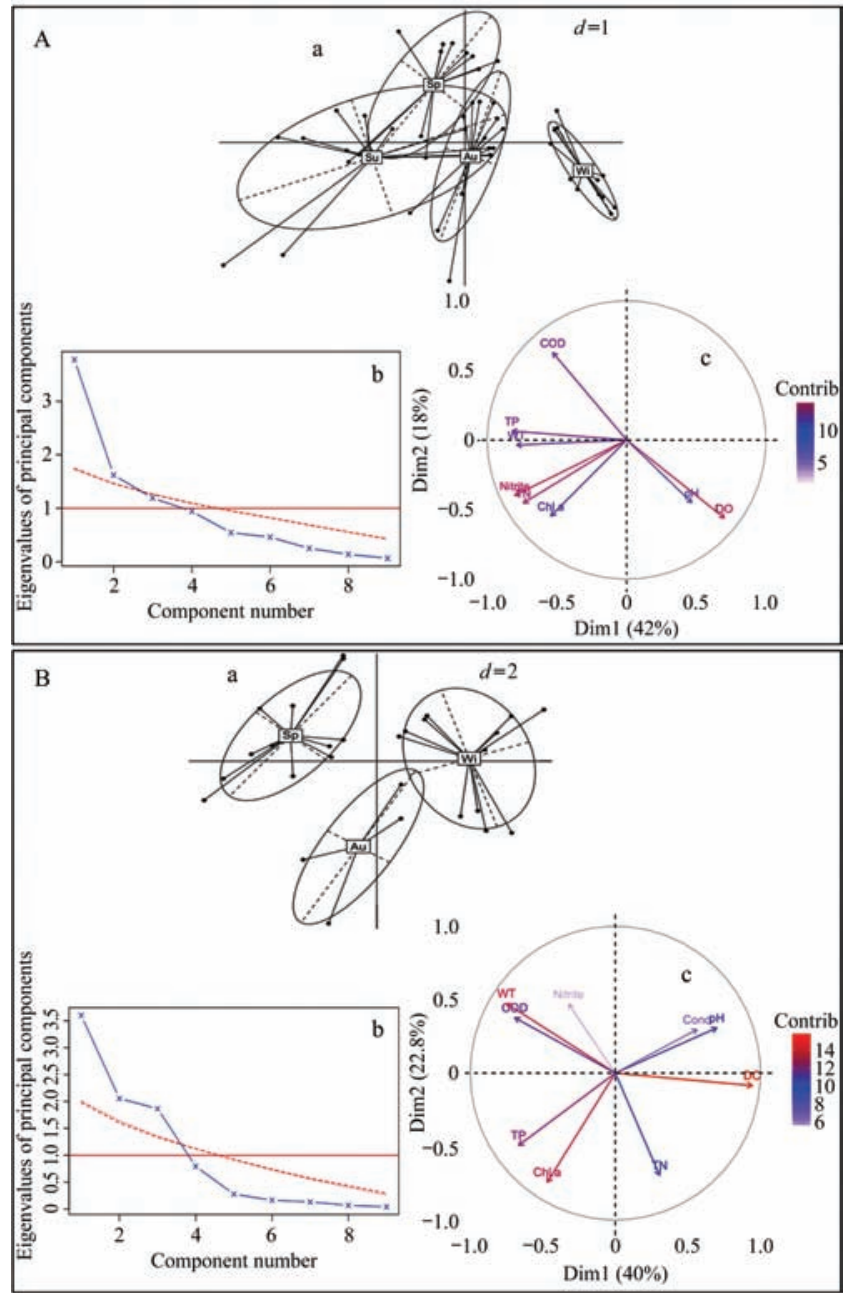

Note: Sp: spring; Su: summer; Au: autumn; Wi: winter. a: ellipsoid represents samples for each season ordinated in the PCA plane; b: Parallel analysis scree plots of the eigenvalues of each PCA axis (principal components were integrally determined by the eigenvalues $>1$, the drastic spinodal in breakline and the intersection of the breakline and dotted line); $\mathrm{c}$ : the correlation circle of environmental variables (COD means $\mathrm{COD}_{\mathrm{Mn}}$, and the darker color means higher contribution). TU and $\mathrm{NH}_{4}{ }^{+}-\mathrm{N}$ were removed to satisfy the requirements in PCA analysis as they were significantly related to WT, TN $(p<0.05)$, respectively.

Figure 4 PCA analysis of trench (A) and rice area (B) water parameters

\subsection{Differences in parameter values between trenches and rice areas}

Mean values measured during the rice fallow period of all parameters were compared between the trench and rice area water. No significant differences were detected for $\mathrm{pH}, \mathrm{NH}_{4}{ }^{+}-\mathrm{N}$ or TP (Figure 2a, 2h, and $2 \mathrm{j}$ ). The mean WT of trench water was significantly higher than rice area water in Nov-Feb $(p<0.01)$ (Figure 2b). A significant higher level of DO of trenches was observed in December, January, February and April $(p<0.05)$ (Figure 2c). Except in November and May, the trench Cond was lower than the rice area, and significant differences were detected in November, March and April $(p<0.01)$ (Figure 2d). TU in trenches was higher than in rice areas, but significant differences were observed only in November and January $(p<0.01)$ (Figure 2e). The differences in $\mathrm{COD}_{\mathrm{Mn}}$ and $\mathrm{NO}_{2}{ }^{-}-\mathrm{N}$ between the trench and rice 
area water were only significant in November $(p<0.05)$ (Figure $2 \mathrm{f}$ and 2i). TN of the trench water was significantly higher in November, and significantly lower in December $(p<0.01)$ than that of rice area water (Figure 2g). Chl. $a$ of the trench was higher than the rice area, excepting in November, and significant differences were observed in February, March and May $(p<0.01)$ (Figure 2k).

\section{Discussion}

Water is the most important single factor for all aquacultural activities. Survival, growth and immunity of $P$. clarkii are dependent on the presence and the quality of water ${ }^{[8]}$, which have been summarized by Ren et al. ${ }^{[18]}$. Unsuited water $\mathrm{pH}$, temperature, DO, $\mathrm{NH}_{4}{ }^{+}-\mathrm{N} \mathrm{NO}_{2}{ }^{-}-\mathrm{N}$, salinity and heavy metal are detrimental and even lethal to P. clarkii. For instance, a WT beyond $32.2^{\circ} \mathrm{C}$, and a DO under $3 \mathrm{mg} / \mathrm{L}$, have been considered to be hypoxic and growth inhibitory to $P$. clarkii, respectively ${ }^{[15,19]}$. Rice growth is also affected by water parameters. It is known that rice seed germination increases with increasing water transparency ${ }^{[20]}$, and increased turbidity may decrease the efficiency of some chemicals commonly added to rice fields ${ }^{[21]}$.

\subsection{Water parameter dynamics in trenches and rice areas}

Yue et al. ${ }^{[22]}$ reported that the maximum survival and weight gain, and highest moult frequency of juvenile $P$. clarkii occurred at $\mathrm{pH} 7.8$ compared with $\mathrm{pH}$ of 6.8 and 8.8 , and suggested the $\mathrm{pH}$ range 7.8-8.5 for juvenile $P$. clarkii. Water $\mathrm{pH}$ in this study ranged from 7.47 to 8.67 , which is close to the range suggested by Yue.

The temperature range suitable for $P$. clarkii is $(21-30)^{\circ} \mathrm{C}$, with the optimum $\sim 23^{\circ} \mathrm{C}^{[23,24]}$, and temperature below $12.8^{\circ} \mathrm{C}$ or above $32.2^{\circ} \mathrm{C}$ has been determined to be detrimental to this crayfish. Research shows that $P$. clarkii has normal feeding and moulting activities at temperature above $12.8^{\circ} \mathrm{C}$ and inhibited growth at temperature above $32.2^{\circ} \mathrm{C}^{[15]}$. Li et al. ${ }^{[25]}$ reported that juvenile $P$. clarkii stopped feeding at a temperature of $5^{\circ} \mathrm{C}-6^{\circ} \mathrm{C}$ and died at $1^{\circ} \mathrm{C}$. The maximum and the minimum instantaneous WT were respectively $39.7^{\circ} \mathrm{C}$ and $2.5^{\circ} \mathrm{C}$ in this study, and there were 22 and 8 days with instantaneously beyond $32.2^{\circ} \mathrm{C}$ and below $5^{\circ} \mathrm{C}$, respectively. Lethal WT could thus occur in Jul-Aug and Dec-Feb. Deepen the trench depth to $\geq 2 \mathrm{~m}$ and increase the trench dike height (to prevent water to enter rice area in the vegetative period of rice) to increase water depths can decrease the stress imposed by the existing extremes in summer and winter.

Hypoxic conditions $(\mathrm{DO}<3 \mathrm{mg} / \mathrm{L})$ is a major limiting factor in crayfish culture $^{[19]}$. Research indicates that a DO level of $2 \mathrm{mg} / \mathrm{L}$ stresses $P$. clarkii and $1 \mathrm{mg} / \mathrm{L}$ is lethal to juveniles ${ }^{[19,26]}$. Typically, nocturnal oxygen consumption due to respiration of crayfish, plants and aerobe and chemical oxidation processes, leads to minimum DO at dawn. In this investigation, DO did not exceed $3 \mathrm{mg} / \mathrm{L}$ in Apr-Jul and the minimum was $<1.5 \mathrm{mg} / \mathrm{L}$. DO at dawn is thus speculated to be lower than the measured values because photosynthesis had begun when water samples were collected (8:00-10:00 AM). DO at dawn in Mar-Sep is probably at hypoxic levels and stress $P$. clarkii in Apr-Jul. High stocking densities further aggravate hypoxic conditions and measures, such as mechanical aeration and water exchange, should be conducted during the warm season to increase DO levels.

Large variations in $\mathrm{TU}$ are common in rice paddies ${ }^{[11]}$. Crayfish bioperturbation of sediments, and foraging and fragmentation on macrophytes both further increase turbidity ${ }^{[9,10]}$, as does crayfish harvesting, plowing and rice transplanting. These factors all lead to higher TU in Apr-Sep. Low TU in Oct-Mar was attributed to the suspension of farming and inactivity of crayfish during the low temperature period. High TU suppresses photosynthesis of hydrophytes and phytoplankton ${ }^{[27]}$, and affects visually dependent predator-prey interactions ${ }^{[28]}$, some measures, such as minimizing bottom disturbance, should be adopted to reduce TU in Apr-Sep.

The main sources of nitrogen and phosphorus in RCIS water is nutrient content of inflow, crayfish feed and feces, fertilizer, aquatic plants, sediment and decomposition of rice straw in rice fallow period. In this study, TN and TP increased slowly Jan-Mar, primarily from slow sediment release of nutrients after feeding suspension and crayfish become inactive. As WT increases in the spring, crayfish become more active, decomposition increases and the release of nutrients from sediment accelerates ${ }^{[12]}$. The addition of feed pellets, sediment disturbance caused by crayfish harvesting and intermittent fertilization during rice transplantation all contributed to the increased TN and TP in Apr-Jul. TN and TP both declined markedly in Aug-Sep, due to decreased feeding, lower crayfish biomass and more frequent water exchange during the hot season. After that, refeeding increased TN and TP instantly. An obvious increase in TN and TP in rice area water Nov-Dec was observed and is attributed to the rapid decomposition of rice straw and roots ${ }^{[29]}$. As large quantities of commercial feed and fertilizer were added to the coculture system during the study, the relatively low levels of water TN and TP would be owing to crayfish and aquatic plant consumption ${ }^{[30]}$, water exchange, and sedimentation $^{[31]}$. Macrophytes in RCIS can absorb large amount of $\mathrm{N}$ and $\mathrm{P}^{[30]}$, and reduce turbidity ${ }^{[32]}$. Further study is needed to evaluate nitrogen and phosphorus sedimentation and loss in water exchange in RCIS. And a good sediment management and maintaining a healthy hydrophyte population should be emphasized.

The factors driving the variation of TN and TP seemed to also drive the variations in $\mathrm{COD}_{\mathrm{Mn}}$ and Chl.a. Typically, the relationships of Chl. $a$ and WT, TN, TP and TU are positive ${ }^{[33]}$. In the study, Chl.a did generally increase with TN and TP, but no obvious relationship between Chl. $a$ and TU was observed.

Ammonia nitrogen is a ubiquitous concern and one of the major limiting factors in crustacean aquaculture, affecting growth, survival and physiology ${ }^{[34]}$. A "safe" concentration of $\mathrm{NH}_{4}{ }^{+}-\mathrm{N}$ to juvenile P.clarkii was reported as $7.94 \mathrm{mg} / \mathrm{L}^{[35]}$, which is much higher than the measured concentration, indicating a low acute ammonia toxic risk for crayfish. The proportion of $\mathrm{NH}_{4}{ }^{+}-\mathrm{N}$ in $\mathrm{TN}$ was relatively high in this study, sometimes more than $60 \%$, and this is consistent with the results of several other studies ${ }^{[12,16,36]}$. Ammonia is produced partially by fertilization, ammonification in sediment and water, organisms corpse decay, and crayfish excretion $(60 \%-90 \% \text { of TN is ammonia in freshwater crustacea })^{[37]}$. These processes lead to a high proportion of $\mathrm{NH}_{4}{ }^{+} \mathrm{N}$ in TN.

Nitrite is formed from the aerobic nitrification of $\mathrm{NH}_{4}{ }^{+}-\mathrm{N}$ and continued oxidation converts $\mathrm{NO}_{2}^{-}-\mathrm{N}$ to $\mathrm{NO}_{3}{ }^{-} \mathrm{N}$. However, nitrification is often limited in rice-crayfish systems for the anoxic condition in sediments ${ }^{[36]}$, leading to low $\mathrm{NO}_{2}{ }^{-}-\mathrm{N}$ levels in this study (0-0.057 mg/L), and far below the "safe" concentration of nitrite to P.clarkii $(2.8 \mathrm{mg} / \mathrm{L}){ }^{[38]}$. Thus, no nitrite toxicity to crayfish was suspected in the investigated water of this study.

PCA analysis showed that water quality parameters in both trenches and rice areas were most correlated with DO, and then with WT and nutrient level, indicating the especial importance of DO, WT and nutrient level monitoring and management. It also indicated the differences of water quality parameters among different seasons. 


\subsection{Comparison of water quality between trenches and rice areas}

WT was higher in the trenches, which serve as a warmer environment for crayfish in winter. During the fallow season, oxygen consumption by rice straw decomposition and zooplankton nourished by the decomposition resulted in lower DO in the rice area water. Water TU in rice areas was lower than in trenches because the sediment in rice areas was more compact and less easily disturbed than in trenches, and some suspended solids adhered to rice straw. The decomposing rice straw produced a massive zooplankton bloom (personal observation) that then consumed phytoplankton, resulting in lower Chl.a content in rice area water than in trenches. Cond, $\mathrm{COD}_{\mathrm{Mn}}, \mathrm{TN}, \mathrm{TP}$ and $\mathrm{NH}_{4}{ }^{+} \mathrm{N}$ in rice area water were generally higher than in trenches, mainly due to the decomposing rice straw, and generally consistent with that in rice-crab coculture systems ${ }^{[13]}$. The differences in water quality between the trenches and rice areas indicate that the two areas constitute different habitats in the rice-crayfish coculture system.

Generally, this work is a primary study of variations of water quality parameters of the most typical RCIS in China, and some underlying driving forces of bio-, physical-, chemical progress are quite complicated, and how these parameters will change with the variations of maintenance in RCIS (e.g. different crayfish stocking densities, field engineering, feeding strategies, and water managements, etc) are still to be understood. Thus, underlying mechanism of these variations and how to maintain a better water environment in Chinese RCIS should be further explored. Furthermore, as severe extreme water parameters (especially for WT and DO) are lethiferous for crayfish, real-time water quality monitoring systems ${ }^{[39]}$ should be used for prejudgement of extreme water factors.

\section{Conclusions}

A monthly measurement of 11 water quality parameters of CRIS in China was conducted, and these parameters were compared between the trenches and rice areas in the rice fallow period. The following conclusions were obtained:

1) Water $\mathrm{pH}, \mathrm{NH}_{4}{ }^{+}-\mathrm{N}, \mathrm{NO}_{2}{ }^{-}-\mathrm{N}$ and Cond were within the suitable ranges for $P$. clarkii, while TU was high during the crayfish harvesting and rice planting season.

2) Annual average TN, TP, $\mathrm{COD}_{\mathrm{Mn}}$ and Chl. $a$ were $<2$ (except in Nov-Dec), 0.25 and $10 \mathrm{mg} / \mathrm{L}$, and $<50 \mathrm{mg} / \mathrm{m}^{3}$, respectively, indicating a relatively low water nutrient level.

3) Extreme WT $\left(>32.2^{\circ} \mathrm{C}\right.$ and $\left.<5^{\circ} \mathrm{C}\right)$ may appear in Jul-Aug and Dec-Feb, respectively, and hypoxic conditions $(\mathrm{DO}<3 \mathrm{mg} / \mathrm{L})$ may appear in Mar-Sep.

4) Water quality parameters in both trenches and rice areas were most correlated with DO, and then with WT and nutrient level, and showed certain seasonal differences.

5) There were certain differences in water parameters between the trench and rice area, i.e., trenches generally had higher TU, WT and DO, and lower TN, TP and $\mathrm{COD}_{\mathrm{Mn}}$. Although no significant differences were found in some months and some parameters, water quality management should be addressed in both trenches and rice areas.

6) Some measures should be conducted to enhance the water fertility, increase DO (especially Mar-Sep), increase the trench and water depth to avoid extreme WT in summer and winter, and improve water quality monitor and anticipation.

\section{Acknowledgements}

This work was financially supported by the Special Fund for Agro-scientific Research in the Public Interest (No. 201203081) and the R \& D Program of the Ministry of Science and Technology of China (Nos. 2012BAD25B06 and 2015BAD13B02). The authors wish to thank Guanghua Guo for allowing us to use his rice plots for this investigation, and Shiyu Jin for her sampling assistance. Special appreciation of Professor David M. Johnson of Ferrum College for his constructive comments on the manuscript.

\section{[References]}

[1] Vromant N, Chau N T H. Overall effect of rice biomass and fish on the aquatic ecology of experimental rice plots. Agr. Ecosyst. Environ., 2005; 111(1): 153-165.

[2] Miao W M. Recent developments in rice-fish culture in China: a holistic approach for livelihood improvement in rural areas. In: De Silva S S, Davy F B (eds) Success stories in Asian aquaculture. Springer Netherlands, Dordrecht, 2010; pp.15-40.

[3] Lu J B, Li X. Review of rice-fish-farming systems in China - one of the globally important ingenious agricultural heritage systems (GIAHS). Aquaculture, 2006; 260(1): 106-113.

[4] Fisheries Administration of the People's Republic of China. China Fishery Statistical Year Book. China Agriculture Press, Beijing, 2016. (in Chinese)

[5] He Y M, Zhang T H. The development status and countermeasures of rice-crayfish culture in China. Scientific Fish Farming, 2011; 3: 1-2. (in Chinese)

[6] Liu Q G, Li Y S, Chen L S. Ecological culture of Procambarus clarkii (4): Crayfish culture in rice fields. Fisheries Science and Technology Information, 2008; 35(4): 186-189. (in Chinese)

[7] Tao Z H, Zhou X, Zhou D Y, Wang S J. Ecological and efficient model and technology of crayfish-rice coculture. China Fisheries, 2013; 7: 68-70. (in Chinese)

[8] Anastácio P M, Nielsen S N, Frias A F, Marques J C. CRISP (crayfish and rice integrated system of production): 4. Modelling water, algae and oxygen dynamics. Ecol. Modell., 1999; 123(1): 29-40.

[9] Rodríguez C F, Bécares E, Fernández-Aláez M. Shift from clear to turbid phase in Lake Chozas (NW Spain) due to the introduction of American red swamp crayfish (Procambarus clarkii). Hydrobiologia, 2003; 506(1-3): 421-426.

[10] Anastácio P M, Correia A M, Menino J P, da Silva L M. Are rice seedlings affected by changes in water quality caused by crayfish? Ann. Limnol.-Int. J. Lim., 2005; 41(1): 1-6.

[11] Halwart M, Gupta M V. Culture of fish in rice fields. Food and Agriculture Organisation and the WorldFish Center, Penang, Malaysia, 2004. 9 p.

[12] Angeler D G, Sánchez-Carrillo S, García G, Alvarez-Cobelas M. The influence of Procambarus clarkii (Cambaridae, Decapoda) on water quality and sediment characteristics in a Spanish floodplain wetland. Hydrobiologia, 2001; 464: 89-98.

[13] Zhang Y J, Wang A, Ma X Z, Wang W, Li Y. Preliminary study on level changes of water quality in rice-crab culture. Guangdong Agric. Sci., 2013; 40(14): 16-19. (in Chinese)

[14] Ni Y H, Sun Q, Wang X L, Zhu J R, Xiao C. Changing characteristices and prediction model of water temperature and dissoved oxygen in Xuyi lobster pond in summer. Chin. Agric. Sci. Bull., 2015; 31(32): 33-39. (in Chinese)

[15] Huner J V, Barr J E. Red swamp crawfish: biology and exploitation (3th ed). Louisiana Sea Grant College Program, Louisiana State University, Baton Rouge, LA, 1991. 128 p.

[16] Mao Z H, Ding F Q, Zhou X, Wang X. Study on the stability of water quality in rice-crayfish rotation. China Fisheries, 2015; 5: 71-72. (in Chinese)

[17] APHA (American Public Health Association). Standard methods for the examination of water and wastewater, 18th ed. American Public Health Association, Washington, DC, 1992.

[18] Ren X L, Ling W H, Ji C P. Effects of the environmental factors on breeding of Procambarus clarkii. Fisheries Science, 2009; 28(11): 710-712. (in Chinese) 
[19] Avault Jr J W, De la Bretonne L W, Huner J V. Two major problems in culturing crayfish in ponds: oxygen depletion and overcrowding. Freshwater Crayfish, 1975; 2: 139-144.

[20] Bellido L L. -Cereales. Mundi-Prensa, Madrid, 1991; 539 p.

[21] Poovey A G, Getsinger K D. Impacts of inorganic turbidity on diquat efficacy against Egeria densa. J. Aquat. Plant Manage., 2002; 40(4): 6-10.

[22] Yue C F, Wang $\mathrm{T} T$, Wang Y F, Peng Y. Effect of combined photoperiod, water calcium concentration and $\mathrm{pH}$ on survival, growth, and moulting of juvenile crayfish (Procambarus clarkii) cultured under laboratory conditions. Aquac. Res., 2009; 40(11): 1243-1250.

[23] Espina S, Herrera F D, Bückle R L F. Preferred and avoided temperatures in the crawfish Procambarus clarkii (Decapoda, Cambaridae). J. Therm. Biol., 1993; 18(1): 35-39.

[24] Bückle R L F, Díaz H F, Espina S. Thermoregulatory behavior applied to the culture of Procambarus clarkii (Decapoda: Cambaridae). Rev. Biol. Trop., 1996; 44(1): 123-126.

[25] Li M, Dong W J, Xing Y C, Gong X J, Wang Y F. Effects of temperature on the development and survival of juvenile Procambarus clarkii. Reservoir Fisheries, 2006; 26(2): 36-37. (in Chinese)

[26] Bonvillain C P, Rutherford D A, Kelso W E, Green C C. Physiological biomarkers of hypoxic stress in red swamp crayfish Procambarus clarkii from field and laboratory experiments. Comp. Biochem. Phys. A, 2012; 163(1): 15-21

[27] Jewson D H, Taylor J A. The influence of turbidity on net phytoplankton photosynthesis in some Irish lakes. Freshwater Bio., 1978; 8(6): 573-584.

[28] Carter M W, Shoup D E, Dettmers J M, Wahl D H. Effects of turbidity and cover on prey selectivity of adult smallmouth bass. T. Am. Fish. Soc., 2010; 139(2): 353-361.

[29] Kunda M, Azim M E, Wahab M A, Dewan S, Roos N, Thilsted S H . Potential of mixed culture of freshwater prawn (Macrobrachium rosenbergii) and self-recruiting small species mola (Amblypharyngodon mola) in rotational rice-fish/prawn culture systems in Bangladesh. Aquac. Res., 2008; 39(5): 506-517.

[30] Cai C F, Gu X H, Huang H Z, Dai X Y, Ye Y T, Shi C J. Water quality, nutrient budget, and pollutant loads in Chinese mitten crab (Eriocheir sinensis) farms around East Taihu Lake. Chin. J. Oceanol. Limn., 2012; 30(1): 29-36

[31] Thakur D P, Lin C K. Water quality and nutrient budget in closed shrimp (Penaeus monodon) culture systems. Aquacult. Eng., 2003; 27(3): 159-176.

[32] Rodríguez C F, Bécares E, Fernández-Aláez M. Shift from clear to turbid phase in Lake Chozas (NW Spain) due to the introduction of American red swamp crayfish (Procambarus clarkii). Hydrobiologia, 2003; 506-509: $421-426$.

[33] Jacoby J M, Collier D C, Welch E B, Hardy F J, Crayton M. Environmental factors associated with a toxic bloom of Microcystis aeruginosa. Can. J. Fish. Aquat. Sci., 2000; 57(1): 231-240.

[34] Romano N, Zeng C S. Toxic effects of ammonia, nitrite, and nitrate to decapod crustaceans: a review on factors influencing their toxicity, physiological consequences, and coping mechanisms. Rev. Fish. Sci., 2013; 21(1): 1-21

[35] Luo J B, Cao Z H, Cai T R, Wen X B. Acute toxic research of ammonia nitrogen on Procambarus clarkii juvenile. Journal of Yangtze University (Nat Sci Edit), 2006; 3(4): 183-185. (in Chinese with English abstract)

[36] Nielsen S N, Anastácio P M, Frias A F, Marques A F J C. CRISP-crayfish rice integrated system of production. 5. Simulation of nitrogen dynamics. Ecol. Modell., 1999; 123(1): 41-52.

[37] Regnault M. Nitrogen excretion in marine and fresh-water crustacea. Biol. Rev., 1987; 62(1): 1-24.

[38] Gutzmer M P, Tomasso J R. Nitrite toxicity to the crayfish Procambarus clarkii. B. Environ. Contam. Tox., 1985; 34(1): 369-376.

[39] Luo H P, Li G L, Peng W F, Song J, Bai Q W. Real-time remote monitoring system for aquaculture water quality. Int J Agr Biol Eng, 2015; 8(6): 136-143. 